\title{
Fuzzy Analytical Hierarchy Process Topsis Untuk Seleksi Pada Anggota Paskibraka
}

\author{
Jhondy Baharsyah', Muliadi'2, Dwi Kartini' ${ }^{3}$ \\ 1,2,3 Prodi Ilmu Komputer FMIPA ULM \\ Jl. A. Yani Km 36 Banjarbaru, Kalimantan selatan \\ 1Email : \hondyBaharsyah@gmail.com
}

\begin{abstract}
Every year Indonesia to conduct the selection of students and high school students and above to be representative of their school as troops heritage flag raisers. During the assessment process for the selection of candidates for members Paskibraka done manually on paper and separate between the assessment criteria for the other criteria, then the assessment results are stored in the form of an excel file. To facilitate the assessment process then takes a decision support system for the selection of candidates for members Paskibraka by applying Fuzzy AHP TOPSIS. Fuzzy AHP TOPSIS method is a convenient method to solve the problem of multi-criteria taking into account the values of the existing criteria. Thus the necessary decision support system using Fuzzy AHP TOPSIS method, in order to help provide recommendations for the decision of selectors prospective team members Paskibraka.
\end{abstract}

Keywords : Fuzzy AHP TOPSIS, Decision Support Systems, Selection

\begin{abstract}
Abstrak
Setiap tahun indonesia melakukan seleksi siswa dan siswi sekolah menengah keatas untuk menjadi perwakilan sekolah mereka sebagai pasukan pengibar bendera pusaka (paskibraka). Selama ini proses penilaian untuk seleksi calon anggota paskibraka dilakukan secara manual di atas kertas dan terpisah antara penilaian untuk kriteria yang satu dengan kriteria yang lainnya, kemudian hasil penilaian tersebut disimpan dalam bentuk file excel. Untuk mempermudah proses penilaian tersebut maka dibutuhkan suatu sistem pendukung keputusan untuk seleksi calon anggota paskibraka dengan menerapkan metode Fuzzy AHP Topsis. Metode Fuzzy AHP Topsis merupakan salah satu metode yang mudah digunakan untuk menyelesaikan masalah multi kriteria dengan memperhitungkan nilai-nilai dari kriteria yang ada. Maka dari itu diperlukan sistem pendukung keputusan menggunakan metode Fuzzy AHP Topsis, supaya dapat membantu memberikan rekomendasi keputusan untuk tim penyeleksi calon anggota paskibraka.
\end{abstract}

Kata kunci : Fuzzy AHP Topsis, Sistem Pendukung Keputusan, Seleksi 


\section{PENDAHULUAN}

Setiap tahun pada setiap daerah di indonesia diselengggarakan seleksi siswa dan siswi sekolah menengah keatas untuk menjadi perwakilan sekolah mereka sebagai pasukan pengibar bendera pusaka (paskibraka), seleksi tingkat provinsi adalah gabungan peserta hasil seleksi tingkat kabupaten/kota, para peserta seleksi diasramakan dan materi seleksi hampir sama dengan tingkat kabupaten/kota tetapi dengan bobot yang lebih tinggi.

Menurut Baharsyah [1\}, selama ini proses penilaian untuk seleksi calon anggota paskibraka dilakukan secara manual di atas kertas dan terpisah antara penilaian untuk kriteria yang satu dengan kriteria yang lainnya, kemudian hasil penilaian tersebut disimpan dalam bentuk file excel. Untuk mempermudah proses penilaian tersebut maka dibutuhkan suatu sistem pendukung keputusan untuk seleksi calon anggota paskibraka dengan menerapkan metode Fuzzy AHP Topsis. Metode Fuzzy AHP Topsis merupakan salah satu metode yang mudah digunakan untuk menyelesaikan masalah multi kriteria dengan memperhitungkan nilai-nilai dari kriteria yang ada.

Berdasarkan uraian diatas maka di perlukan metode Fuzzy AHP Topsis untuk mendukung pengambilan keputusan pemilihan anggota paskibraka, supaya dapat membantu memberikan rekomendasi keputusan untuk tim penyeleksi dinas pemuda olahraga pariwisata dan kebudayaan kalimantan selatan, dalam menentukan calon anggota paskibraka.

\section{METODE PENELITIAN}

\subsection{Metode Fuzzy}

Sebuah himpunan fuzzy adalah kelas objek dengan nilai keanggotaan yang kontinum. Seperti yang ditetapkan ditandai dengan fungsi keanggotaan (karakteristik) yang diberikan ke setiap objek kelas keanggotaan berkisar antara nol dan satu. Menurut Rouhani ${ }^{[2]}$ beberapa definisi penting dasar fuzzy set yang dikutip sebagai berikut:

a. Sejumlah fuzzy segitiga dapat didefinisikan oleh bilangan segitiga $\left(a_{1}, a_{2}, a_{3}\right)$ Fungsi keanggotaan $\mu_{\text {ã }}[x]$ didefinisikan seperti

$$
\mu_{\tilde{a}}[x]= \begin{cases}0 ; & x \leq a_{1} \\ \frac{x-a_{1}}{a_{2}-a_{1}} ; & a_{1}<x \leq a_{2} \\ \frac{a_{2}-x}{a_{2}-a_{2}} ; & a_{2}<x \leq a_{3} \\ 0 ; & x \geq a_{3}\end{cases}
$$

b. Jika yang dua bilangan fuzzy segitiga yang masing-masing ditunjukkan oleh $\left(a_{1}, a_{2}, a_{3}\right)$ dan $\left(b_{1}, b_{2}, b_{3}\right)$ dan , maka hukum operasional dari dua bilangan fuzzy segitiga adalah sebagai berikut:

$$
\begin{aligned}
& \tilde{a}(+) \tilde{b}=\left(a_{1}, a_{2}, a_{3}\right)(+)\left(b_{1}, b_{2}, b_{3}\right)=\left(a_{1}+b_{1}, a_{2}+b_{2}, a_{3}+b_{3}\right) \\
& \tilde{a}(-) \tilde{b}=\left(a_{1}, a_{2}, a_{3}\right)(-)\left(b_{1}, b_{2}, b_{3}\right)=\left(a_{1}-b_{1}, a_{2}-b_{2}, a_{3}-b_{3}\right)
\end{aligned}
$$




$$
\begin{aligned}
& \tilde{a}(x) \tilde{b}=\left(a_{1}, a_{2}, a_{3}\right)(x)\left(b_{1}, b_{2}, b_{3}\right)=\left(a_{1} x b_{1}, a_{2} x b_{2}, a_{3} x b_{3}\right) \\
& \tilde{a}(/) \tilde{b}=\left(a_{1}, a_{2}, a_{3}\right)\left(\mathcal{S}\left(b_{1}, b_{2}, b_{3}\right)=\left(a_{1} / b_{1}, a_{2} / b_{2}, a_{3} / b_{3}\right)\right. \\
& k \tilde{a}=\left(a_{1}, a_{2}, a_{3}\right)
\end{aligned}
$$

c. Sebuah variabel linguistik yang hadir dengan kata-kata seperti penggunaan yang sangat rendah, rendah, sedang, tinggi, sangat tinggi untuk menggambarkan kondisi yang kompleks. Nilai-nilai linguistik juga dapat direpresentasikan oleh bilangan fuzzy.

d. Jika $\tilde{a}$ dan $\tilde{b}$ yang dua bilangan fuzzy segitiga yang telah ditunjukkan oleh triplet masing-masing $\left(a_{1}, a_{2}, a_{3}\right)$ dan $\left(b_{1}, b_{2}, b_{3}\right)$, maka metode vertex digunakan untuk menentukan jarak antara a dan $b$ adalah:

$$
d(\tilde{a}+\tilde{b})=\sqrt{\frac{1}{3}}\left[\left(a_{1}-b_{1}\right)^{2}+\left(a_{2}-b_{2}\right)^{2}+\left(a_{3}-b_{3}\right)^{2}\right]
$$

e. Tertimbang normalisasi matriks keputusan fuzzy dibuat dari formula di bawah ini:

$$
\begin{aligned}
& \tilde{v}=\left[\tilde{v}_{i j}\right]_{n x j} \mathrm{i}=1,2, \ldots . . . \mathrm{n} \text { dan } \mathrm{j}=1,2, \ldots . . \mathrm{m} \\
& \tilde{\mathrm{v}}_{\mathrm{ij}}=\tilde{x}_{\mathrm{ij}} X \widetilde{w}_{i}
\end{aligned}
$$

Satu set presentasi rating alternative $A_{j}=(j=1,2, \ldots, m)$ dengan kriteria $C_{i}=(i=1,2, \ldots, n)$. Satu set bobot pentingnya setiap kriteria $W_{i}$ dengan $i=1,2 \ldots . n$ dan $\left(\tilde{x}=\tilde{x}_{\mathrm{ij}}, i=1,2, . ., n, j=1,2, . ., m\right)$

Metode Fuzzy AHP merupakan gabungan metode $A H P$ dengan pendekatan konsepfuzzy. Metode pendukung keputusan Fuzzy AHP menitikberatkan pada fuzzifikasi nilai pada matriks perbandingan berpasangan yang sebelumnya berupa bilangan klasik pada $A H P$. 
Tabel 1. Tabel Skala Chang untuk Perbandingan Skala Kriteria

\begin{tabular}{|c|c|c|c|}
\hline $\begin{array}{c}\text { Intensitas } \\
\text { Kepentingan } \\
\text { AHP }\end{array}$ & Himpunan Linguistik & $\begin{array}{l}\text { Tringular } \\
\text { Fuzzy Number } \\
\text { (TFN) }\end{array}$ & $\begin{array}{l}\text { Reciprocal } \\
\text { (Kebalikan) }\end{array}$ \\
\hline 1 & $\begin{array}{l}\text { Perbandingan elemen yang sama } \\
\text { (Just Equal) }\end{array}$ & $(1,1,1)$ & $(1,1,1)$ \\
\hline 2 & Pertengahan (Intermediate) & $(1 / 2,1,3 / 2)$ & $(2 / 3,1,2)$ \\
\hline 3 & $\begin{array}{l}\text { Elemen satu cukup penting dari yang } \\
\text { lainnya (Moderately Important) }\end{array}$ & $(1,3 / 2,2)$ & $(1 / 2,2 / 3,1)$ \\
\hline 4 & $\begin{array}{l}\text { Pertengahan (Intermediate) elemen } \\
\text { satu lebih cukup penting dari yang } \\
\text { lainnya }\end{array}$ & $(3 / 2,2,5 / 2)$ & $\begin{array}{c}(2 / 5,1 / 2 \\
2 / 3)\end{array}$ \\
\hline 5 & $\begin{array}{l}\text { Elemen satu kuat pentingnya dari } \\
\text { yang lain (Strongly Important) }\end{array}$ & $(2,5 / 2,3)$ & $\begin{array}{c}(1 / 3,2 / 5 \\
1 / 2)\end{array}$ \\
\hline 6 & Pertengahan (Intermediate) & $(5 / 2,3,7 / 2)$ & $\begin{array}{l}(2 / 7,1 / 3 \\
2 / 5)\end{array}$ \\
\hline 7 & $\begin{array}{l}\text { Elemen satu lebih kuat pentingnya } \\
\text { dari yang lain (Very Strong) }\end{array}$ & $(3,7 / 2,4)$ & $\begin{array}{c}(1 / 4,2 / 7 \\
1 / 3)\end{array}$ \\
\hline 8 & Pertengahan (Intermediate) & $(7 / 2,4,9 / 2)$ & $\begin{array}{c}(2 / 9,1 / 4 \\
2 / 7)\end{array}$ \\
\hline 9 & $\begin{array}{l}\text { Elemen satu mutlak lebih penting } \\
\text { dari yang lainnya (Extremely Strong) }\end{array}$ & $(4,9 / 2,9 / 2)$ & $\begin{array}{c}(2 / 9,2 / 9 \\
1 / 4)\end{array}$ \\
\hline
\end{tabular}

Sumber : Fuzzy Analytical Hierarchi Process Topsis Untuk Seleksi Pada Anggota Paskibraka.2016

Nilai intensitas kepentingan suatu elemen dalam metode FAHP adalah bilangan fuzzy yang memiliki batas ketidak jelasan. Oleh karena itu, digunakan extent analysis method untuk mempertimbangkan tingkat kepuasan atau sejauh mana suatu objek yang terpilih dapat memenuhi tujuan. Dengan $C=\{c 1, c 2, \ldots, \mathrm{cm}\}$ sebagai criteria set, nilai vektor bobot dapat diperoleh dengan langkah-langkah sebagai berikut:

a. Definisikan nilai fuzzy synthetic extent $\left(\hat{S}_{\mathrm{i}}\right)$ untuk $i$-objek seperti persamaan berikut:

Dengan :

$$
\tilde{S} i=\sum_{j=1}^{m} \widetilde{M}_{c i}^{j} \odot\left[\sum_{i=1}^{n} \sum_{j=1}^{m} \widetilde{M}_{c i}^{j}\right]^{-1}
$$

$$
\sum_{j=1}^{m} \widetilde{M}_{c i}^{j}=\left(\sum_{j=1}^{m} l_{j}, \sum_{j=1}^{m} m_{j}, \sum_{j=1}^{m} u_{j}\right)
$$

dimana $\widetilde{M}_{c i}^{j}$ adalah bilangan fuzzy untuk $j$-kriteria dan $\odot$ didefinisikan sebagai fuzzy untuk perkalian. Sehingga untuk memperoleh nilai $\left[\sum_{i=1}^{n} \sum_{j=1}^{m} \widetilde{M}_{c i}^{j}\right]^{-1}$ dilakukan operasi invers dari persamaan.

$$
\left[\sum_{i=1}^{n} \sum_{j=1}^{m} \widetilde{M}_{c i}^{j}\right]=\left(\sum_{i=1}^{m} l_{i}, \sum_{i=1}^{m} m_{i}, \sum_{i=1}^{m} u_{i}\right)
$$


Menurut Chang ${ }^{[3]}$ Menentukan nilai vektor $(V)$ dan nilai ordinat defuzzifikasi $\left(d^{\prime}\right)$. Untuk mendapatkan estimasi nilai bobot untuk masing-masing kriteria, perlu mempertimbangkan prinsip perbandingan antar bilangan fuzzy.

Maka nilai vektor untuk $\widetilde{M}_{2} \geq \widetilde{M}_{1}\left(\widetilde{M}_{1}=\left(l_{1}, m_{1}, u_{1}\right)\right.$ dan $\left.\widetilde{M}_{2}=\left(l_{2}, m_{2}, u_{2}\right)\right)$ dapat dirumuskan sebagai berikut:

$$
V\left(M_{2} \geq M_{1}\right)=\left\{\begin{array}{cc}
1 & \text {,jika } m_{2} \geq m_{1} \\
0 & , \text { jika } l_{1} \geq u_{2} \\
\frac{\left(l_{1}-u_{2}\right)}{\left(m_{2}-u_{2}\right)-\left(m_{1}-l_{1}\right)}, & \text { yang lainnya } .
\end{array}\right.
$$

$d$ merupakan ordinat titik perpotongan tertinggi antara $\mu_{\widetilde{M}_{1}}$, dan $\mu_{\widetilde{M}_{2}}$, dan untuk membandingkan $\widetilde{M}_{1}=\left(l_{1}, m_{1}, u_{1}\right)$ dan $\widetilde{M}_{2}=\left(l_{2}, m_{2}, u_{2}\right)$ digunakan rumus sebagai berikut :

$$
d^{\prime}\left(A_{1}\right)=\min V\left(S_{1} \geq S_{k}\right) \text { untuk } k=1,2, \ldots, n ; k \neq i
$$

Sehingga vector bobot didefinisikan sebagai berikut :

$$
W^{\prime}=\left(d^{\prime}\left(A_{1}\right), d^{\prime}\left(A_{2}\right), \ldots, d^{\prime}\left(A_{n}\right)\right)^{T}
$$

b. Menormalisasi vektor bobot pada persamaan di atas menjadi:

$$
W=\left(d\left(A_{1}\right), d\left(A_{2}\right), \ldots, d\left(A_{n}\right)\right)^{T}
$$

dimana W merupakan bilangan klasik yang merupakan prioritas lokal.

\subsection{Fuzzy Topsis}

Menurut Onet [4], Langkah-langkah metode TOPSIS Fuzzy yang diperkenalkan sebagai berikut:

a. Memilih nilai linguistik $\tilde{x}_{\mathrm{ij}}$ untuk alternatif mengenai kriteria. Rating linguistik fuzzy membuat rentang normal bilangan fuzzy segitiga yaitu [0,1], maka tidak ada kebutuhan untuk normalisasi.

b. Menghitung matriks keputusan normalisasi

$$
\tilde{V}_{\mathrm{ij}}=\tilde{x}_{\mathrm{ij}} \mathrm{X} w_{i}
$$

c. Menentukan solusi ideal positif dan solusi ideal negative dari persamaan berikut:

$$
\begin{aligned}
& A^{*}=\left\{V^{*} \ldots, V_{i}^{*}\right\}=\left\{\left(\max \tilde{V}_{i j} / i \in \Omega b\right),\left(\min \tilde{V}_{i j} / i \in \Omega c\right)\right\} \\
& A^{-}=\left\{V^{-} \ldots . V^{-}\right\}=\left\{\left(\min \tilde{V}_{i j} / i \in \Omega b\right),\left(\max \tilde{V}_{i j} / i \in \Omega c\right)\right\}
\end{aligned}
$$

Adalah set kriteria keuntungan dan adalah set kriteria biaya.

d. Menghitung jarak setiap alternatif dari solusi ideal dengan persamaan berikut: 


$$
\begin{aligned}
& D_{i}^{*}=\sum_{J=1}^{m} d\left(\tilde{V}_{i j} A^{*}\right) i=1,2, \ldots \ldots n \\
& D_{i}^{-}=\sum_{J=1}^{m} d\left(\tilde{V}_{i j} A^{-}\right) i=1,2, \ldots \ldots n
\end{aligned}
$$

e. Menghitung kesamaan dengan solusi ideal :

$$
F C_{i}=\frac{D_{i}^{-}}{D^{i}+D^{+}}
$$

Algoritma metode Fuzzytopsis, yakni :

a. Meranking fuzzy dari setiap pembuat keputusan, $D_{k} ;(k=1,2,3, \ldots, K)$ dapat direpresentasikan sebagai angka segitiga fuzzy $R_{k} ;(k=1,2,3, \ldots, K)$ dengan fungsi keanggotaan $\mu_{R}^{\tilde{r}}(\mathrm{x})$.

b. Menentukan evaluasi kriteria.

c. Selajutnya, penyesuaian variabel linguistik untuk mengevaluasi kriteria dan alternatif.

d. Setelah bobot kriteria terpenuhi. Perankingan fuzzy dapat dicari dengan rumus

$$
R_{k}^{\sim}(a, b, c), k=1,2,3, \ldots, K
$$

dengan

$$
a=\min \left\{a_{\mathrm{k}}\right\} \mathrm{b}=\frac{1}{k} \sum_{k-1}^{k} b_{\mathrm{k},} c=\max \{c k\} .
$$

e. Membentuk matriks keputusan D mengacu terhadap m alternatif yang akan dievaluasi berdasarkan $\mathrm{n}$ kriteria yang didefinisikan sebagai berikut :

$$
\tilde{D}=\left[\begin{array}{cccc}
\tilde{x}_{11} & \tilde{x}_{12} & \cdots & \tilde{x}_{1 n} \\
\tilde{x}_{21} & \tilde{x}_{22} & \cdots & \tilde{x}_{2 n} \\
\vdots & \vdots & \cdots & \vdots \\
\tilde{x}_{m 1} & \tilde{x}_{m 2} & \cdots & \tilde{x}_{m n}
\end{array}\right]
$$

dengan $\tilde{x}_{\mathrm{ij}}$ menyatakan performansi dari perhitungan untuk alternatif ke-i terhadap atribut ke-j.

Nilai bobot preferensi menunjukkan tingkat kepentingan relatif setiap kriteria atau subkriteria. Nilai bobot dapat dihitung menggunakan rumus

$$
W=\left\{w_{1}, w_{2}, w_{3}, \ldots, w_{n}\right\}
$$

dimana $x^{\kappa_{i j}}$ dan $\tilde{w}_{j}{ }^{k}$ adalah variabel linguistik yang dapat ditunjukkan dengan nilai segitiga fuzzy : $\tilde{x}_{i j}=\left(a_{i j}, b_{i j}, c_{i j}\right)$ dan $w_{i j}^{\sim}=\left(w_{j 1}, w_{j 2}, w_{j 3}\right)$. 
f. Menentukan matriks keputusan yang ternormalisasi. Matriks ternormalisasi terbentuk dari rumus

$$
R_{i j}=\frac{x_{i j}}{\sqrt{\sum_{i=1}^{m} x_{i j}^{2}}}
$$

dengan $\mathrm{B}$ dan $\mathrm{C}$ adalah himpunan dari atribut benefit dan cost, dengan

$$
\begin{gathered}
\tilde{r}_{i j}=\left(\frac{a_{i j}}{c_{j}^{+}}, \frac{b_{i j}}{c_{j}^{+}}, \frac{c_{i j}}{c_{j}^{+}}\right), j \in B \\
\tilde{r}_{i j}=\left(\frac{a_{j}^{-}}{c_{i j}}, \frac{a_{j}^{-}}{b_{i j}}, \frac{a_{j}^{-}}{a_{i j}}\right), j \in C \\
C^{+}=\max c i j j \in B \text { dan } a^{-}=\min a i j, j \in C
\end{gathered}
$$

g. Menghitung matriks keputusan yang ternormalisasi terbobot. Menghi-tung matriks ternomalisasi terbobot dihitung menggunakan rumus

$$
\tilde{v}=\left[\tilde{v}_{i j}\right]_{m x n,} i=1,2,3, \ldots, m ; j=1,2,3, \ldots, n
$$

h. Menghitung matriks soludi ideal positif $A^{+}$dan matriks solusi ideal negatif $A^{-}$

$$
\begin{aligned}
& A^{+}=\left(\tilde{v}_{1}^{+}, v_{2}{ }^{+}, v_{3}^{+}, \ldots, \tilde{v}_{n}^{+}\right) \\
& A^{-}=\left(v_{1}{ }^{-}, v_{2}^{-}, v_{3^{3}}, \ldots, v_{n^{-}}{ }^{-}\right) \text {. }
\end{aligned}
$$

i. Menghitung jarak antara nilai setiap alternatif dengan matriks solusi ideal positif dan matrik solusi ideal negatif. Jarak alternatif $\left(d_{i}{ }^{+}\right)$dengan solusi ideal positif dirumuskan sebagai berikut :

$$
D_{i}^{+}=\sum_{j=1}^{n} \quad d\left(\tilde{V}_{i j}, \tilde{V}_{j}^{+}\right) ; i=1,2,3 \ldots . . . m .
$$

Jarak alternatif $\left(\mathrm{d}_{\mathrm{i}}{ }^{-}\right)$dengan solusi ideal negatif dirumuskan sebagai berikut :

$$
D_{i}^{-}=\sum_{j=1}^{n} \quad d\left(\tilde{V}_{i j}, \tilde{V}_{j}^{-}\right) ; i=1,2,3 \ldots . . . m .
$$

j. $\quad$ Menghitung nilai preferensi untuk setiap alternatif. Nilai preferensi $\left(\mathrm{CC}_{\mathrm{i}}\right)$ untuk setiap alternatif dirumuskan sebagai berikut :

$$
C C_{i}=\frac{d^{-}}{d^{+}+d^{-}} ; i=1,2,3, \ldots, m \text { dengan } 0<C C_{i}<1
$$

\section{HASIL DAN PEMBAHASAN}

Dalam kasus ini terdapat tujuh kriteria, yaitu wawancara, parade, PBB, kesenian, psikotes, pengetahuan umum dan tes fisik. Berdasarkan kriteria dan alternatif yang tersedia maka dapat dibuat struktur hirarki keputusan untuk seleksi pemilihan paskibraka. 
a. Kriteria.

Tabel 2. Keterangan Kode Kriteria

\begin{tabular}{cl}
\hline Kode & \multicolumn{1}{c}{ Keterangan } \\
\hline C1 & Parade \\
C2 & PBB \\
C3 & Psikotes \\
C4 & Tes Fisik \\
C5 & Wawancara \\
C6 & Kesenian Daerah \\
C7 & Pengetahuan Umum \\
\hline
\end{tabular}

Sumber : Fuzzy Analytical Hierarchi Process Topsis Untuk Seleksi Pada Anggota Paskibraka.2016

b. Kode Alternatif

Tabel 3. Keterangan Kode Alternatif

\begin{tabular}{cl}
\hline Kode & \multicolumn{1}{c}{ Keterangan } \\
\hline A1 & Edi Purwanto \\
A2 & Muhammad Rifai \\
A3 & Reza Wahyudi \\
\hline
\end{tabular}

Sumber : Fuzzy Analytical Hierarchi Process Topsis Untuk Seleksi Pada Anggota Paskibraka.2016

a. Langkah-Langkah Penilaian Seleksi Paskibraka Berdasarkan Extend Analysis 1) Proses Pengambilan Keputusan untuk Kriteria

a) Matriks Perbandingan Kepentingan Antar Kriteria

Untuk membuat matriks perbandingan kepentingan antar kriteria pertama-tama kita harus menentukan tingkat kepentingan satu kriteria dengan kriteria yang lainnya dengan mengacu pada Skala Triangular Fuzzy Menurut Chang ${ }^{[3]}$ pada tabel 4:

Tabel 4. Skala kepentingan AHP Chang

\begin{tabular}{|c|c|c|c|}
\hline $\begin{array}{l}\text { Intensitas } \\
\text { Kepentingan } \\
\text { AHP }\end{array}$ & Himpunan Linguistik & $\begin{array}{l}\text { Triangular Fuzzy } \\
\text { Number (TFN) }\end{array}$ & $\begin{array}{l}\text { Reciprocal } \\
\text { (Kebalikan) }\end{array}$ \\
\hline 1 & Perbandingan elemen yang sama (Just Equal) & $(1, \mathbf{1}, 1)$ & $(1, \mathbf{1}, 1)$ \\
\hline 2 & Pertengahan (Intermediate) & $(1 / 2,1,3 / 2)$ & $(2 / 3,1,2)$ \\
\hline 3 & $\begin{array}{l}\text { Elemen satu cukup penting dari yang lainnya } \\
\text { (moderately important) }\end{array}$ & $(1,3 / 2,2)$ & $(1 / 2,2 / 3,1)$ \\
\hline 4 & $\begin{array}{l}\text { Pertengahan (Intermediate) elemen satu lebih cukup } \\
\text { penting dari yang lainnya) }\end{array}$ & $(3 / 2,2,5 / 2)$ & $(2 / 5,1 / 2,2 / 3)$ \\
\hline 5 & $\begin{array}{l}\text { Elemen satu kuat pentingnya dari yang lain } \\
\text { (Strongly Important) }\end{array}$ & $(2, \mathbf{5} / \mathbf{2}, 3)$ & $(1 / 3,2 / 5,1 / 2)$ \\
\hline 6 & Pertengahan (Intermediate) & $(5 / 2,3,7 / 2)$ & $(2 / 7, \mathbf{1} / \mathbf{3}, 2 / 5)$ \\
\hline 7 & $\begin{array}{l}\text { Elemen satu lebih kuat pentingnya dari yang lain (Very } \\
\text { Strong) }\end{array}$ & $(3,7 / 2,4)$ & $(1 / 4,2 / 7,1 / 3)$ \\
\hline 8 & Pertengahan (Intermediate) & $(7 / 2,4,9 / 2)$ & $(2 / 9, \mathbf{1} / \mathbf{4}, 2 / 7)$ \\
\hline 9 & $\begin{array}{l}\text { Elemen satu mutlak lebih penting dari yang lainnya } \\
\text { (Extremely Strong) }\end{array}$ & $(4,9 / 2,9 / 2)$ & $(2 / 9,2 / 9,1 / 4)$ \\
\hline
\end{tabular}


Tabel 5. Matriks Perbandingan Kepentingan Berpasangan Antar Kriteria

\begin{tabular}{cccccccc}
\hline & $\mathrm{c} 1$ & $\mathrm{c} 2$ & $\mathrm{c3}$ & $\mathrm{c4}$ & $\mathrm{c5}$ & $\mathrm{c6}$ & $\mathrm{c7}$ \\
\hline $\mathrm{c1}$ & 1 & 1 & $1 / 2$ & $1 / 4$ & 3 & 3 & 2 \\
$\mathrm{c} 2$ & 1 & 1 & $1 / 2$ & $1 / 4$ & 3 & 3 & 2 \\
$\mathrm{c} 3$ & 2 & 2 & 1 & $1 / 3$ & 4 & 4 & 3 \\
c4 & 4 & 4 & 3 & 1 & 5 & 5 & 4 \\
c5 & $1 / 3$ & $1 / 3$ & $1 / 4$ & $1 / 5$ & 1 & 1 & $1 / 2$ \\
c6 & $1 / 3$ & $1 / 3$ & $1 / 4$ & $1 / 5$ & 1 & 1 & $1 / 2$ \\
c7 & $1 / 2$ & $1 / 2$ & $1 / 3$ & $1 / 4$ & 2 & 2 & 1 \\
\hline
\end{tabular}

Sumber : Fuzzy Analytical Hierarchi Process Topsis

Untuk Seleksi Pada Anggota Paskibraka.2016

Selanjutnya matriks penbandingan antar kriteria tersebut akan dikonveris menjadi triangular fuzzy number (TFN) dengan mengacu pada tabel skala kepentingan AHP. Hasil dari konversi ke matriks perbandingkan kepentingan dengan nilai fuzzy adalah

Tabel 6. Matriks Perbandingan Kepentingan Berpasangan Antar Kriteria skala fuzzy triangular number

\begin{tabular}{lrrrrrrrrrrrr}
\hline Kriteria & \multicolumn{1}{c}{$\mathrm{c} 1$} & \multicolumn{1}{c}{$\mathrm{c} 2$} & \multicolumn{1}{c}{$\mathrm{c} 3$} & \multicolumn{3}{c}{$\mathrm{c} 4$} \\
\hline $\mathrm{c1}$ & 1 & 1 & 1 & 1 & 1 & 1 & 0.67 & 1 & 2 & 0.4 & 0.5 & 0.67 \\
$\mathrm{c2}$ & 1 & 1 & 1 & 1 & 1 & 1 & 0.67 & 1 & 2 & 0.4 & 0.5 & 0.67 \\
c3 & 0.5 & 1 & 1.5 & 0.5 & 1 & 1.5 & 1 & 1 & 1 & 0.5 & 0.67 & 1 \\
c4 & 1.5 & 2 & 2.5 & 1.5 & 2 & 2.5 & 1 & 1.5 & 2 & 1 & 1 & 1 \\
c5 & 0.5 & 0.67 & 1 & 0.5 & 0.67 & 1 & 0.4 & 0.5 & 0.67 & 0.33 & 0.4 & 0.5 \\
c6 & 0.5 & 0.67 & 1 & 0.5 & 0.67 & 1 & 0.4 & 0.5 & 0.67 & 0.33 & 0.4 & 0.5 \\
c7 & 0.67 & 1 & 2 & 0.67 & 1 & 2 & 0.5 & 0.67 & 1 & 0.4 & 0.5 & 0.67 \\
\hline
\end{tabular}

Sumber : Fuzzy Analytical Hierarchi Process Topsis Untuk Seleksi Pada Anggota Paskibraka.2016

Tabel 7. Tabel kriteria

\begin{tabular}{lrrrrrrrrr}
\hline kriteria & \multicolumn{1}{c}{ c5 } & \multicolumn{3}{c}{ c6 } & \multicolumn{3}{c}{ c7 } \\
\hline c1 & 1 & 1.5 & 2 & 1 & 1.5 & 2 & 0.5 & 1 & 1.5 \\
c2 & 1 & 1.5 & 2 & 1 & 1.50 & 2 & 0.5 & 1 & 1.5 \\
c3 & 1.5 & 2 & 2.5 & 1.5 & 2.00 & 2.5 & 1 & 1.5 & 2 \\
c4 & 2 & 2.5 & 3 & 2 & 2.5 & 3 & 1.5 & 2 & 2.5 \\
c5 & 1 & 1 & 1 & 1 & 1 & 1 & 0.67 & 1 & 2 \\
c6 & 1 & 1 & 1 & 1 & 1 & 1 & 0.67 & 1 & 2 \\
c7 & 0.5 & 1 & 1.5 & 0.5 & 1 & 1.5 & 1 & 1 & 1 \\
\hline \multicolumn{4}{c}{ Sumber : Fuzzy Analytical Hierarchi Process Topsis }
\end{tabular}

Kemudian kita akan mencari nilai total baris dan kolom dari dari tabel matriks nilai fuzzy sebelumnya: 
Tabel 8. Total baris dan kolom dari

fuzzy triangular number

\begin{tabular}{|c|c|c|}
\hline \multicolumn{3}{|c|}{ Total Baris } \\
\hline l & & U \\
\hline 5.57 & 7.5 & 10.17 \\
\hline 5.57 & 7.5 & 10.17 \\
\hline 6.5 & 9.17 & 12 \\
\hline 10.5 & 13.5 & 16.5 \\
\hline 4.4 & 5.23 & 7.17 \\
\hline 4.4 & 5.23 & 7.17 \\
\hline 4.23 & 6.17 & 9.67 \\
\hline 41.17 & 54.3 & 72.83 \\
\hline
\end{tabular}

Sumber : Fuzzy Analytical Hierarchi Process

Topsis Untuk Seleksi Pada Anggota Paskibraka.2016

b) Nilai Sintesis Fuzzy

Setelah nilai jumlah baris dan kolom diperoleh dari masing-masing matriks perbandingan, selanjutnya menggunakan persamaan (8) :

$$
S i=\sum_{j=1}^{m} M^{j}{ }_{g i} \odot\left[\sum_{i=1}^{n} \sum_{i=1}^{n} M^{j} g_{i}\right]^{-1}
$$

Hasil perhitungan untuk nilai sintesis fuzzy di atas dapat ditabelkan

Tabel 9. Nilai Sintesis Fuzzy Untuk Kriteria

\begin{tabular}{lrrr}
\hline \multicolumn{4}{c}{ matriks sintetis } \\
\hline & $\mathrm{l} 1$ & \multicolumn{3}{c}{$\mathrm{m} 1$} & $\mathrm{u} 1$ \\
S1 & 0.08 & 0.14 & 0.25 \\
S2 & 0.08 & 0.14 & 0.25 \\
S3 & 0.09 & 0.17 & 0.29 \\
S4 & 0.14 & 0.25 & 0.40 \\
S5 & 0.06 & 0.10 & 0.17 \\
S6 & 0.06 & 0.10 & 0.17 \\
S7 & 0.06 & 0.11 & 0.24 \\
\hline
\end{tabular}

Sumber : Fuzzy Analytical Hierarchi Process Topsis

Untuk Seleksi Pada Anggota Paskibraka.2016

c) Derajat Keanggotaan

Untuk mendapatkan derajat keanggotaan digunakan persamaan (11):

$$
V\left(M_{2} \geq\left\{\begin{array}{cl}
1, & \text { jika } m_{2} \geq m_{1} \\
0, & \text { jika } l_{1} \geq u_{2} \\
\frac{l_{1}-u_{2}}{\left(m_{2}-u_{2}\right)-\left(m_{1}-l_{1}\right)}, & \text { untuk nilai } \\
\text { yang lain }
\end{array}\right.\right.
$$


Setelah derajat keanggotaan semua kriteria dihitung, maka hasil perhitungan selanjutnya ditabelkan seperti tabel berikut ini:

Tabel 10. Derajat Keanggotaan untuk kriteria

\begin{tabular}{lrrrrrrrrr}
\hline V & S1 & & S2 & \multicolumn{1}{l}{ S3 } & S4 & S5 & S6 & S7 & min V \\
\hline S1 & 1 & 1 & 0.84 & 0.48 & 1 & 1 & 1 & 0.48 \\
S2 & 1 & 1 & 0.84 & 0.48 & 1 & 1 & 1 & 0.48 \\
S3 & 1 & 1 & 1 & 0.65 & 1 & 1 & 1 & 0.65 \\
S4 & 1 & 1 & 1 & 1 & 1 & 1 & 1 & 1 \\
S5 & 0.70 & 0.70 & 0.54 & 0.16 & 1 & 1 & 0.87 & 0.16 \\
S6 & 0.70 & 0.70 & 0.54 & 0.16 & 1 & 1 & 0.87 & 0.16 \\
S7 & 0.87 & 0.87 & 0.73 & 0.40 & 1 & 1 & 1 & 0.40 \\
\hline \multicolumn{8}{c}{ Sumber : Fuzzy Analytical Hierarchi Process Topsis } \\
& \multicolumn{8}{c}{ Untuk Seleksi Pada Anggota Paskibraka.2016 } &
\end{tabular}

d) Normalisasi Bobot Vektor

Setelah menetukan bobot vektor untuk masing-masing kriteria, akan dilakukan normalisasi bobot vektor. Normalisasi bobot vektor diperoleh dengan membagi masing-masing elemen pada $W^{\prime}$ dengan jumlah keseluruhan elemen pada $W^{\prime}$.

Tabel 11. Normalisasi Bobot Vektor untuk Kriteria

\begin{tabular}{ccccccccr}
\hline $\mathrm{W}^{\prime}$ & 0.48 & 0.48 & 0.65 & 1 & 0.16 & 0.16 & 0.40 & 3.34 \\
\hline $\mathrm{W}$ & 0.14 & 0.14 & 0.19 & 0.30 & 0.05 & 0.05 & 0.12 & 1 \\
\hline \multicolumn{2}{l}{ Sumber : Fuzzy Analytical Hierarchi Process Topsis Untuk Seleksi Pada Anggota Paskibraka.2016 }
\end{tabular}

b. Perangkingan

Selanjutnya untuk perangkingan akan digunakan perhitungan TOPSIS dengan sampel data peserta seleksi dengan nilai untuk masing-masing kriteria sebagai berikut:

Tabel 12. Tabel nilai peserta untuk masing-masing kriteria

\begin{tabular}{lrrrrrrrr}
\hline Nama & Parade & PBB & Psikotes & & Tes Fisik & Wawancara & Kesenian & Pengetahuan \\
\hline A1 & 78 & 67 & 56 & 98 & 89 & 100 & 78 \\
A2 & 90 & 89 & 67 & 89 & 87 & 85 & 56 \\
A3 & 70 & 89 & 67 & 78 & 65 & 77 & 88 \\
\hline
\end{tabular}

Sumber : Fuzzy Analytical Hierarchi Process Topsis Untuk Seleksi Pada Anggota Paskibraka.2016

Langkah yang pertama kali dilakukan adalah menghitung matriks ternormalisasi (R) dengan membagi nilai setiap kolom dengan akar kuadrat dari total penjumlahan kuadrat total kolom setiap kriteria digunakan persamaan(25):

$$
R_{i j}=\frac{x_{i j}}{\sqrt{\sum_{i=1}^{m} x_{i j}^{2}}}
$$


Kemudian bagi nilai setiap kolom dengan total kolom dari masing-masing kriteria, sehingga dihasilkan tabel seperti berikut:

Tabel 13. Nilai kolom dibagi total kolom kriteria

\begin{tabular}{lrlrrrrr}
\hline Nama & Wawancara & Parade & PBB & Kesenian & Psikotest & Peng. Umum & Tes Fisik \\
\hline A1 & $78 / 138.1$ & $67 / 142.59$ & $56 / 110.06$ & $98 / 153.65$ & $89 / 140$ & $100 / 152.16$ & $78 / 130.25$ \\
A2 & $90 / 138.1$ & $89 / 142.59$ & $67 / 110.06$ & $89 / 153.65$ & $87 / 140$ & $85 / 152.16$ & $56 / 130.25$ \\
A3 & $70 / 138.1$ & $89 / 142.59$ & $67 / 110.06$ & $78 / 153.65$ & $65 / 140$ & $77 / 152.16$ & $88 / 130.25$ \\
\hline
\end{tabular}

Sumber : Fuzzy Analytical Hierarchi Process Topsis

Untuk Seleksi Pada Anggota Paskibraka.2016

Setelah diproses maka akan dihasilkan tabel nilai matriks ternormalisasi seperti di bawah ini:

Tabel 14. Nilai matriks ternormalisasi

\begin{tabular}{|c|c|c|c|c|c|c|c|}
\hline $\mathrm{R}$ & Parade & PBB & Psikotes & $\begin{array}{l}\text { Tes } \\
\text { Fisik }\end{array}$ & Wawancara & Kesenian & Pengetahuan \\
\hline $\begin{array}{c}\text { Tot. } \\
\text { kolom }\end{array}$ & 138.1 & 142.59 & 110.06 & 153.65 & 140.41 & 152.16 & 130.25 \\
\hline A1 & 0.56 & 0.47 & 0.51 & 0.64 & 0.63 & 0.66 & 0.60 \\
\hline A2 & 0.65 & 0.62 & 0.61 & 0.58 & 0.62 & 0.56 & 0.43 \\
\hline A3 & 0.51 & 0.62 & 0.61 & 0.51 & 0.46 & 0.51 & 0.68 \\
\hline
\end{tabular}

Sumber : Fuzzy Analytical Hierarchi Process Topsis

Untuk Seleksi Pada Anggota Paskibraka.2016

Kemudian dihitung nilai matriks terbobot (Y) yaitu nilai yang sudah ternormalisasi dikalikan bobot fuzzy masing-masing kriteria. Kemudian akan dicari nilai solusi ideal positif $(\mathrm{A}+)$ yang didapatkan dari nilai max masingmasing kriteria dan nilai solusi ideal negative (A-) yang didapatkan dari nilai min masing-masing kriteria.

Berdasarkan perhitungan di atas maka didapatkan matriks terbobot Y seperti tabel berikut ini:

Tabel 15. Nilai matriks ternormalisasi terbobot

\begin{tabular}{cccccccc}
\hline Y & Parade & PBB & Psikotes & Tes Fisik & Wawancara & Kesenian & Pengetahuan \\
\hline Bobot & 0.14 & 0.14 & 0.19 & 0.30 & 0.05 & 0.05 & 0.12 \\
A1 & 0.08 & 0.07 & 0.10 & 0.19 & 0.03 & 0.03 & 0.07 \\
A2 & 0.09 & 0.09 & 0.12 & 0.17 & 0.03 & 0.03 & 0.05 \\
A3 & 0.07 & 0.09 & 0.12 & 0.15 & 0.02 & 0.02 & 0.08 \\
\hline
\end{tabular}

Sumber : Fuzzy Analytical Hierarchi Process Topsis

Untuk Seleksi Pada Anggota Paskibraka.2016

Langkah selanjutnya adalah mencari jarak ideal positif $(\mathrm{A}+)$ dan jarak ideal negatif $(A-)$

Tabel 16. Nilai solusi ideal positif dan negatif

\begin{tabular}{lccccccr}
\hline $\mathrm{A}+(\max )$ & 0.09 & 0.09 & 0.11 & 0.19 & 0.03 & 0.03 & 0.08 \\
\hline $\mathrm{A}-(\min )$ & 0.07 & 0.07 & 0.10 & 0.15 & 0.02 & 0.02 & 0.05 \\
\hline \multicolumn{5}{l}{ Sumber : Fuzzy } & Analytical Hierarchi Process Topsis Untuk Seleksi Pada Anggota Paskibraka.2016
\end{tabular}


Langkah selanjutnya adalah mencari jarak solusi ideal positif (D+) dan jarak solusi ideal negatif (D-) yang dihitung dengan rumus persamaan (30):

$$
\left.D_{i}^{+}=\sqrt{\sum_{j=1}^{n}\left(y_{i}^{+}\right.}-y_{i j}\right)^{2} ; i=1,2, \ldots, m \text {. }
$$

Berdasarkan perhitungan di atas maka didapatkan nilai seperti dalam tabel berikut ini:

Tabel 17. Nilai jarak solusi ideal positif dan negatif

\begin{tabular}{lrr}
\hline Nama & D+ & \multicolumn{2}{c}{ D- } \\
\hline A1 & 0.03 & 0.05 \\
A2 & 0.03 & 0.04 \\
A3 & 0.05 & 0.04 \\
\hline
\end{tabular}

Sumber : Fuzzy Analytical Hierarchi Process Topsis Untuk Seleksi Pada Anggota Paskibraka.2016

Langkah terakhir adalah mencari nilai preferensi setiap alternatif yang dapat dihitung dengan rumus persamaan (32):

$$
V_{i}=\frac{D_{i}^{-}}{D_{i}^{-}+D_{i}^{+}} \text {, dimana } i=1,2,3, \ldots . . m
$$

Dari hasil perhitungan didapatkan nilai preferensi (Vi) setiap peserta dan hasil alternatif yang memiliki nilai preferensi terbesar maka memiliki ranking yang tertinggi karena semua data kriteria yang digunakan termasuk dalam kategori benefit.

Tabel 18. Nilai preferensi dan ranking alternatif

\begin{tabular}{lrr}
\hline Nama & Vi & \multicolumn{2}{c}{ Ranking } \\
\hline A1 & 0.58 & 1 \\
A2 & 0.55 & 2 \\
A3 & 0.48 & 3 \\
\hline
\end{tabular}

Sumber : Fuzzy Analytical Hierarchi Process Topsis Untuk Seleksi Pada Anggota Paskibraka.2016

Berikut ini perbandingan bobot kriteria untuk perhitungan manual dan bobot kriteria hasil dari proses sistem pendukung keputusan seleksi paskibraka:

Tabel 19. Perbandingan nilai bobot kriteria

\begin{tabular}{clll}
\hline Kode & \multicolumn{1}{c}{ Nama Kriteria } & \multicolumn{1}{c}{ Bobot Asli } & \multicolumn{1}{c}{ Bobot Hasil SPK } \\
\hline C1 & Parade & $15 \%$ & $(0,144) 14,4 \%$ \\
C2 & PBB & $15 \%$ & $(0,144) 14,4 \%$ \\
C3 & Psikotes & $20 \%$ & $(0,194) 19,4 \%$ \\
C4 & Tes Fisik & $30 \%$ & $(0,299) 29,99 \%$ \\
C5 & Wawancara & $5 \%$ & $(0,049) 4,9 \%$ \\
C6 & Kesenian Daerah & $5 \%$ & $(0,049) 4,9 \%$ \\
C7 & Pengetahuan Umum & $10 \%$ & $(0,12) 12 \%$ \\
\hline
\end{tabular}




\section{(1)}

$\begin{array}{lll}\text { Total } & 100 \% & \text { (1) } 100 \%\end{array}$

Sumber : Fuzzy Analytical Hierarchi Process Topsis Untuk Seleksi Pada Anggota Paskibraka.2016

Kemudian berikut ini merupakan perbandingan hasil perangkingan dari aplikasi dan hasil perangkingan asli dari pihak Dinas Pemuda Olahraga dan Kebudayaan Provinsi Kalimantan Selatan:

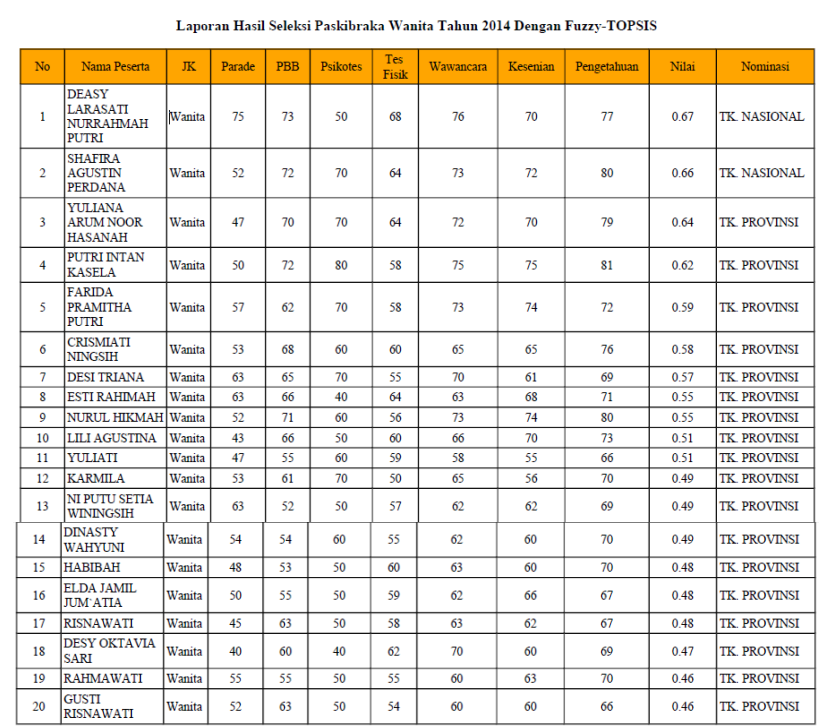

Gambar 1. Laporan Aplikasi SPK Perangkingan Seleksi Paskibaraka Wanita Sumber : Fuzzy Analytical Hierarchi Process Topsis Untuk Seleksi Pada Anggota Paskibraka.2016

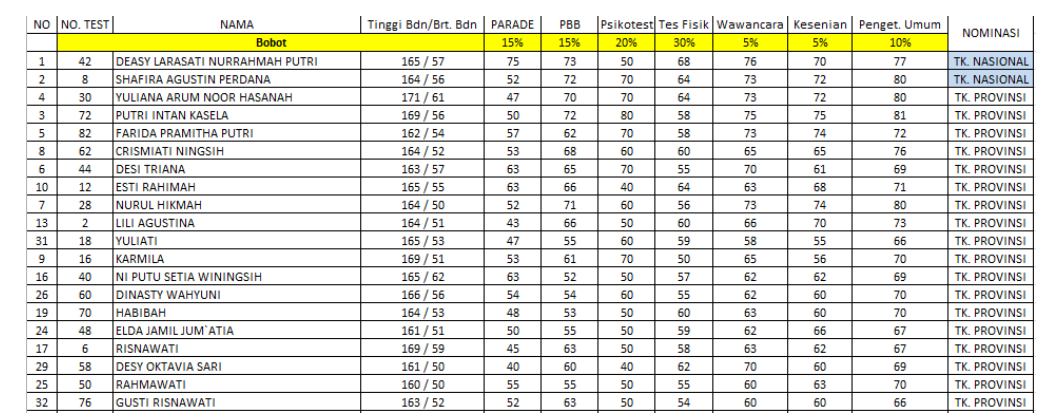

Gambar 2. Laporan Asli Perangkingan Seleksi Paskibaraka Wanita Sumber : Fuzzy Analytical Hierarchi Process Topsis Untuk Seleksi Pada Anggota Paskibraka.2016 


\begin{tabular}{|c|c|c|c|c|c|c|c|c|c|c|c|}
\hline No & Nama Peserta & JK & Parade & PBB & Psikotes & $\begin{array}{l}\text { Tes } \\
\text { Fisik }\end{array}$ & Wawancara & Kesenian & Pengetaluaan & Nilai & Nominasi \\
\hline 1 & \begin{tabular}{|l|} 
TITO ARI \\
PRIARSO
\end{tabular} & Pria & 78 & 74 & 80 & 73 & 75 & 77 & 81 & 0.86 & TK NASIONAL \\
\hline 2 & $\begin{array}{l}\begin{array}{l}\text { SATRIA DWI } \\
\text { PUTERA }\end{array} \\
\end{array}$ & Pria & 66 & 72 & 80 & 62 & 73 & 68 & 76 & 0.7 & TK NASIONAL \\
\hline 3 & $\begin{array}{l}\text { GAGAS AKBAR } \\
\text { ROBYANTOKO }\end{array}$ & Pria & 58 & 66 & 70 & 64 & 68 & 77 & 80 & 0.67 & TK PROVINSI \\
\hline 4 & ROBBY HERMAN & Pria & 65 & 65 & 50 & 73 & 63 & 62 & 73 & 0.67 & \begin{tabular}{|l|} 
TK PROVINSI \\
\end{tabular} \\
\hline 5 & $\begin{array}{l}\text { AJENBAGOES } \\
\text { RAMADHAN }\end{array}$ & Pria & 48 & 67 & 80 & 59 & 67 & 76 & 73 & 0.61 & TK PROVINSI \\
\hline 6 & LUKMAN HAKIM & Pria & 48 & 68 & 50 & 69 & 73 & 65 & 68 & 0.6 & \begin{tabular}{|l|} 
TK PROVINSI \\
\end{tabular} \\
\hline 7 & AHMAD SYARIF & Pria & 53 & 69 & 50 & 65 & 78 & 62 & 75 & 0.59 & \begin{tabular}{|l|} 
TK PROVINSI \\
\end{tabular} \\
\hline 8 & \begin{tabular}{|l|} 
AHMAD \\
MASHUR
\end{tabular} & Pria & 53 & 66 & 40 & 72 & 71 & 62 & 69 & 0.59 & TK PROVINSI \\
\hline 9 & $\begin{array}{l}\text { MUHAMMMAD } \\
\text { MAHYUDIN }\end{array}$ & Pria & 45 & 68 & 50 & 67 & 74 & 61 & 73 & 0.58 & TK PROVINSI \\
\hline 10 & $\begin{array}{l}\text { TOPAN DWI } \\
\text { SETTYONO }\end{array}$ & Pria & 43 & 63 & 60 & 62 & 60 & 63 & 68 & 0.55 & TK PROVINSI \\
\hline 11 & AULIA RAHMAN & Pria & 38 & 68 & 50 & 66 & 67 & 83 & 67 & 0.55 & TK PROVINSI \\
\hline 12 & \begin{tabular}{|l} 
IKSAN \\
MAHENDRA \\
APRIYANTO
\end{tabular} & Pria & 45 & 66 & 50 & 02 & 68 & 65 & 76 & 0.53 & TK PROVINSI \\
\hline 13 & $\begin{array}{l}\text { MUTAMMMAD } \\
\text { NOOR }\end{array}$ & Pria & 65 & 59 & 40 & 63 & 66 & 60 & 69 & 0.53 & TK PROVINSI \\
\hline 14 & $\begin{array}{l}\text { AHMAD RIZKI } \\
\text { MAULANA }\end{array}$ & Pria & 62 & 55 & 50 & $\infty 0$ & 67 & 60 & 73 & 0.53 & TK PROVINSI \\
\hline 15 & $\begin{array}{l}\text { JAFFAR SADIQ } \\
\text { AL-HADAD }\end{array}$ & Pria & 42 & 63 & 50 & 64 & 67 & 74 & 66 & 0.53 & TK. PROVINSI \\
\hline 16 & $\begin{array}{l}\text { MUHAMMAD } \\
\text { DANAR } \\
\text { ANGGARA }\end{array}$ & Pria & 45 & 59 & 50 & 62 & 75 & 68 & 81 & 0.53 & TK. PROVINSI \\
\hline 17 & \begin{tabular}{|l|} 
DEDEN \\
RAMADHAN \\
\end{tabular} & Pria & 60 & 63 & 50 & 57 & 60 & 60 & 66 & 0.51 & TK. PROVINSI \\
\hline 18 & $\begin{array}{l}\text { REYNALDI } \\
\text { HAKIM }\end{array}$ & Pria & 46 & 65 & 60 & 56 & 60 & 65 & 70 & 0.51 & TK. PROVINSI \\
\hline 19 & \begin{tabular}{|l} 
Aת LAKSONO \\
PRIHAMBODO
\end{tabular} & Pria & 40 & 62 & 70 & 53 & 77 & 67 & 75 & 0.5 & TK. PROVINSI \\
\hline 20 & $\begin{array}{l}\text { NOR RAHMAT } \\
\text { JAROT }\end{array}$ & Pria & 48 & 64 & 50 & 59 & 60 & 60 & 66 & 0.5 & TK. PROVINSI \\
\hline 21 & $\begin{array}{l}\text { MUHAMMMAD } \\
\text { RDZALUL } \\
\text { RAHMAN }\end{array}$ & Pria & 67 & 57 & 40 & 58 & 62 & 70 & 68 & 0.49 & TK. PROVINSI \\
\hline
\end{tabular}

Gambar 3. Laporan Aplikasi SPK Perangkingan Seleksi Paskibaraka Pria Sumber : Fuzzy Analytical Hierarchi Process Topsis Untuk Seleksi Pada Anggota Paskibraka.2016

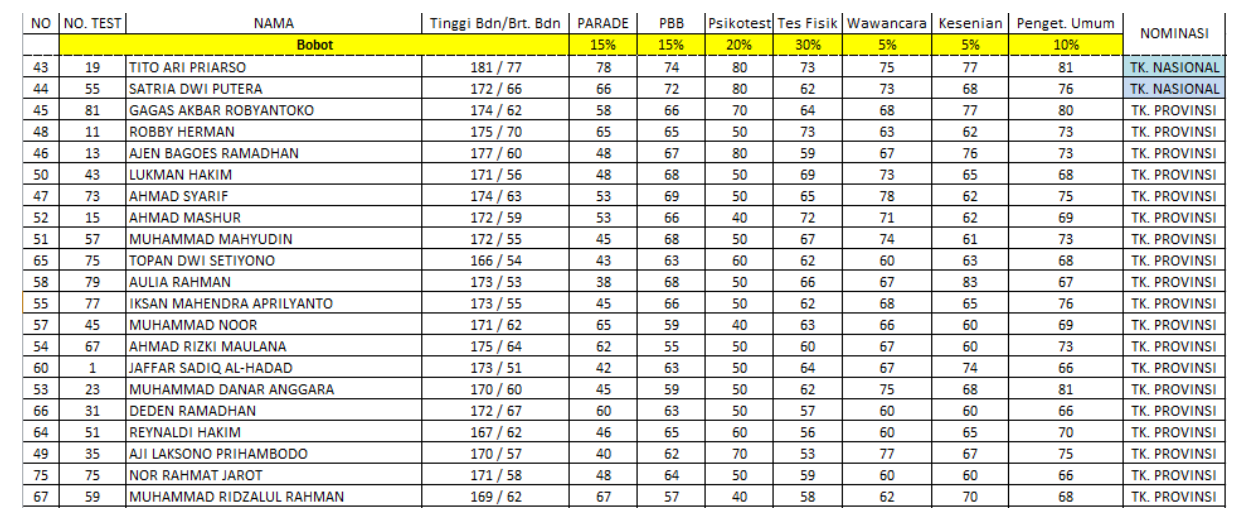

Gambar 4. Laporan Asli Perangkingan Seleksi Paskibaraka Pria Sumber : Fuzzy Analytical Hierarchi Process Topsis Untuk Seleksi Pada Anggota Paskibraka.2016

\section{Simpulan}

Dari hasil penelitian dan pengamatan dari sistem yang telah dilakukan, dapat disimpulkan bahwa kendala yang terjadi dalam penelitian dengan metode Fuzzy AHP TOPSIS ini adalah banyaknya penilaian perbandingan kepentingan antar kriteria, karena semakin banyak kriteria yang digunakan maka semakin banyak pula nilai perbandingkan kepentingan antar kriteria yang diperlukan. 


\section{DAFTAR PUSTAKA}

[1] Baharsyah, Jhondy. 2016. Fuzzy AHP Topsis Untuk Seleksi Pada Anggota Paskibraka. Program S-1 Ilmu Komputer, Universitas Lambung Mangkurat: Banjarbaru.

[2] Amiri, M.P., 2010. Project Selection for Oil-.elds Development by Using AHP and fuzzy TOPSIS methods. Expert System with Application, 37, 6218-6224

[3] Ashrafzadeh, Maysam, dkk. 2012. Application Of Fuzzy Topsis Method For The Selection Of Warehouse Location: A Case Study Vol. 3, No 9. Islamic Azad University. Iran.

[4] Dewi, Sri Kusuma; Sri Hartati. 2006. Fuzzy Multi Attribute Decision Making (Fuzzy-MADM"). Penerbit Andi. Yogyakarta.

[5] Kabir, Golam; M. Ahsan Akhtar Hasin. 2012. Multiple Criteria Inventory Classification Using Fuzzy Analytic Hierarchy Process. Bangladesh University of Science and Technology. Bangladesh.

[6] Kusrini. 2007. Konsep dan Aplikasi Sistem Pendukung Keputusan, Penerbit Andi. Yogyakarta.

[7] Raharjo dkk. 2002. Aplikasi Fuzzy Analytical hierarchy Process dalam Seleksi Karyawan. Jurnal Teknik Industri. Vol 4, no. 2 halaman 82-92

[8] Sarfaraz, Ahmad; Kouroush Jenab. 2012. A Fuzzy Conceptual Design Selection Model Considering Conflict Resolution Vol. 4, No. 1.

[9] Tang, Yu-Cheng; Malcolm J. Beynon. 2005. Application and Development of a Fuzzy Analytic Hierarchy Process within a Capital Investment Study Vol. 1, No. 2. 